\title{
Relation between Hand of Bath Towel and Physical Properties
}

\author{
Nishimatsu Toyonori ${ }^{\text {a }}{ }^{*}$, Kanai Hiroyuki ${ }^{\text {a }}$, Fujiwara Megumi ${ }^{\text {a }}$, TAKahashi Kyouhei ${ }^{\text {a }}$, \\ Kishine Nobuyuki ${ }^{\text {b }}$, Fujita Hatsume ${ }^{\text {b }}$, Furuta Asako ${ }^{b}$, Masukawa Ayako ${ }^{\text {b }}$ \\ ${ }^{a}$ Faculty of Textile Science and Technology, Shinshu University, 3-15-1 Tokida, Ueda-shi, Nagano 386-8567, Japan \\ ${ }^{\mathrm{b}}$ Rhohin Keikaku Co., Ltd, 4-26-3 Higashi-ikebukuro, Toshima-ku, Tokyo 170-8424, Japan
}

Received 8 August 2014; accepted for publication 14 October 2014

\begin{abstract}
The hand is one of the important qualities of bath towels. It is interesting to study what physical properties of bath towels correlate to their hand. In this paper, the relationship between the sensory values for the good feel and physical properties of twelve bath towels was studied by means of the principle regression analysis and the correlation analysis. The results are as follows.

(1) As a result of principal component analysis, it was found that two principal component "good in touch" and "sturdy and drying property" were chosen to represent the hand of bath towel.

(2) The compression feeling was affected by compression properties((To-TM), compression ratio, compression energy, and recovery energy). And the softness feeling was affected by the friction property(MMD), and the warmth by the thermal property(q-max).
\end{abstract}

Key Words : Hand, Bath towel, Principal component analysis, Compression property, Friction property

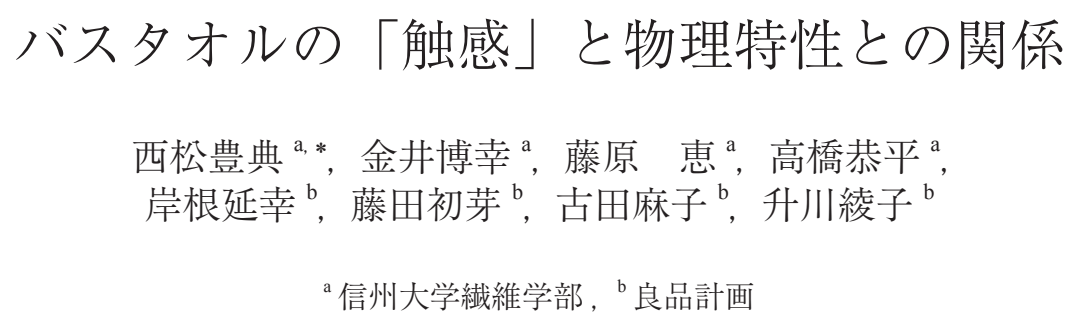

\section{1. 緒 言}

バスタオルは, JIS [1] によれば「大形長方形で, ふろ上 がり，シャワーを浴びたときに用いるタオル」と定義されて いる. 日本では入浴が日常的な生活習慣として定着している ことを考慮すると, バスタオルは年齢や性別を問わず毎日使 用されるものといえる.

2012 年 8 月に実施されたインターネットによるアンケート 調查結果 [2]（20～50 代男性 118 名, 女性 116 名）によると, 消費者がバスタオルを購入する時に「肌触りの良さ」,「吸水 性の良さ」, 「丁度よい厚さ」, 「丁度よい重さ」,「乾燥しやす さ」を重視すると報告している．

タオルの「触感」に関する研究は数多く行われている. 例 えば, 西松らはバスタオルについて評価した「良感触性」と
物理特性との関係より,「良感触性」は重量, 圧縮特性, 動 摩擦係数が関係していること $[3,4]$, 消費者及び専門家がバ スタオルの触感を評価した結果より両者に共通な評価形容語 は「ソフト感, 厚さ, ふっくら感, なめらかさ」であること, 各形容語を評価するときに消費者は重量, 専門家は圧縮特性, 摩擦特性, 重量, 厚さを重視すること [5], バスタオルの触 感と物理特性間に任意次数の微分・積分を適用した結果, 消 費者は夕オルの変位量, 専門家は変形速度を刺激として受容 したときに触感が生じること [6], 消費者及び専門家がカラー タオル織物の触感を視覚と触知覚, 触知覚だけ, 視覚だけで 評価したとき, 程度の差はあるが両者とも触知覚に対する視 覚優位の統合を生じること [7], 視覚と触知覚でカラータオ ル織物の触感を評価するときにどちらの情報に依存するかに ついて情報理論を用いて解析した結果, 消費者の方が専門家

* 連絡先：信州大学繊維学部先進繊維工学課程 386-8567 上田市常田 3-15-1

E-mail : toyo@shinshu-u.ac.jp, Tel : +81-268-21-5379, Fax : +81-268-21-5598 
Table 1 Samples.

\begin{tabular}{|c|c|c|c|c|c|c|c|c|c|c|}
\hline \multirow[b]{2}{*}{ Sample } & \multirow{2}{*}{\multicolumn{2}{|c|}{$\begin{array}{c}\text { Pile yarn } \\
\text { twist level(tpi) }\end{array}$}} & \multicolumn{3}{|c|}{ Yarn count(s) } & \multirow[b]{2}{*}{ Pile ratio } & \multicolumn{2}{|c|}{ Density } & \multirow{2}{*}{$\begin{array}{l}\text { Thick } \\
{[\mathrm{mm}]}\end{array}$} & \multirow{2}{*}{$\begin{array}{l}\text { Weight } \\
{\left[\mathrm{g} / \mathrm{m}^{2}\right]}\end{array}$} \\
\hline & & & pile & warp & weft & & $\begin{array}{c}\text { warp } \\
\text { [ends/inch] }\end{array}$ & $\begin{array}{c}\text { weft } \\
\text { [picks/inch] }\end{array}$ & & \\
\hline (1) & \multirow{10}{*}{ twist } & Z9.9 & 42.1 & 21.7 & 32.9 & 5.1 & 36.4 & 56.0 & 2.02 & 202.8 \\
\hline (2) & & Z10.5 & 20.3 & $20.8 / 2$ & 28.9 & 7.7 & 38.4 & 58.2 & 4.28 & 506.1 \\
\hline (3) & & Z10.5/S8.1 & $3.4 / 2$ & $32.1 / 2$ & 16.7 & 3.0 & 37.0 & 42.0 & 3.57 & 426.8 \\
\hline (4) & & $\mathrm{Z} 10.4 / \mathrm{S} 10.3$ & $30.0 / 2$ & 20.4 & 19.4 & 4.6 & 37.0 & 50.0 & 2.92 & 349.1 \\
\hline (5) & & Z12.1/S3.8 & $41.8 / 2$ & $41.4 / 2$ & 21.9 & 7.5 & 37.0 & 52.0 & 4.23 & 419.4 \\
\hline (6) & & Z9.6/S9.8 & $31.7 / 2$ & $30.7 / 2$ & $31.6 / 2$ & 6.1 & 38.0 & 48.0 & 5.47 & 553.4 \\
\hline (7) & & Z12.6 & 20.8 & $32.8 / 2$ & 15.3 & 6.9 & 38.0 & 46.6 & 4.05 & 481.2 \\
\hline 8 & & Z13.4 & 21.2 & $31.6 / 2$ & 20.1 & 7.4 & 38.0 & 54.0 & 4.51 & 460.5 \\
\hline (9) & & Z9.8 & 20.7 & $40.9 / 2$ & 20.1 & 5.6 & 38.0 & 53.2 & 3.16 & 354.4 \\
\hline (10) & & $Z 7.5$ & 33.1 & $42.4 / 2$ & 31.1 & 7.1 & 39.2 & 65.4 & 3.08 & 326.4 \\
\hline (11) & \multirow{2}{*}{ twistless } & $0.0 / \mathrm{S} 10.1$ & $53.6 / 2$ & $43.2 / 2$ & 21.1 & 9.3 & 35.4 & 54.6 & 6.06 & 432.8 \\
\hline (12) & & 0.0 & 66.0 & $43.6 / 2$ & 22.3 & 8.6 & 34.8 & 60.0 & 3.89 & 230.9 \\
\hline
\end{tabular}

より約 $20 \%$ 多く視觉情報量に依存することを明らかにして いる [8]. 高寺ら [9] は糸密度, パイル倍率, パイル糸の 撚り数が異なる夕オルの触感は「表面のなめらかさ, ボリュー 么感」で評価されること, 触感には圧縮特性と曲げ特性が関 係していることを明らかにした．Singh らはタオルの厚さ， 重量, 圧縮特性, 摩擦特性より夕オルの風合いを表わす 4 形 容語と総合風合いの客観評価式を提案し，専門家が評価した 官能量と評価式より求めた值とによい一致がみられたと報告 している [10]. しかし, これらの研究では官能検査に用い られた形容語が「良感触性」だけ，あるいは物理特性に関連 した形容語のみを用いていること, 官能検査を行っている被 験者が 20 代男性や専門家に限定されている.

そこで, 本研究ではバスタオルの主な購入層である20～ 50 代の女性が代表的な市販バスタオルの「触感」に関連する 種々の形容語について触知覚のみで官能検查を行った，そし て, 評価された「触感」評価形容語について主成分分析を用 いてバスタオルの「触感」を評価する主要因を検討した。さ らに,「触感」評価量とタオルの「触感」に関連する物理特性 (圧 縮特性, 摩擦特性, 温熱特性) や基本特性（目付, 厚さ, 糸 番手数, 系密度, パイル倍率) との相関関係について考察した。

\section{2. 試料及び実験方法}

\section{1 試料}

タオル商社の専門家が市販されているバスタオルの中か ら, 触感が異なる 12 種類のバスタオルを選定した。これら は全て綿 $100 \%$ の両面パイル・バスタオルである. 本実験で 用いた 12 種類のバスタオルの詳細を Table 1 に示す。

\section{2 バスタオルの「触感」官能検査}

ヒトが物に触れたときに感じる対象物の触感は,「温冷感」, 「硬軟感」,「乾湿感」,「粗滑感」で表現されるといわれてい
る [11]，そこで，4 種類の触感をそれぞれ表現する 6 種類の 形容語（あたたかい一冷たい，やわらかい一かたい，しなや かなーごわごわした，しっとりしたー乾いた，なめらかなー ざらざらした，すべりやすいーすべりにくい）を物理形容語 として選定した。

同様にして，バスタオルの基本特性に関連する 4 種類の形 容語（重い一軽い，厚い一薄い，大きい一小さい，パイルが 長い一短い), 消費者が求める「肌触りのよいバスタオル」 のイメージ調查結果 [2] から 9 種類の形容語（ふんわりし たーやせた, 吸水性がよさそう一悪そう,がっしりしたーがっ しりしていない，高級感がある一ない，肌になじむ一なじま ない，乾きやすそう一乾きにくそう，がさがさしたーがさが さしない，肌触りがよい一悪い，好き一嫌い）をイメージ形 容語として選定した

被験者は主なバスタオル購入層である 20～50 代の女性 40 名（20 代；10 名，30 代；9 名，40 代；11 名，50 代；10 名）とした。 バスタオル購入時を想定して,「大きいー小さい」 を評価するときには被験者の視覚情報は遮断しなかったが, 他の形容語については触った印象で評価をするように被験者 へ指示した，実験室内のテーブル上に 12 種類の試料を各 2 枚ずつ設置した，各試料は，Fig. 1 に示すように， 1 枚は Fig. 1(a)のように店頭に並んだバスタオル（12 枚折り）を再現し た。他の 1 枚は重ねないで, 1 枚のバスタオル（破線で囲っ た部分)を触って評価するために Fig. 1(b)のように設置した。

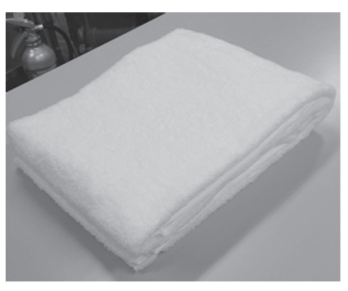

(a)

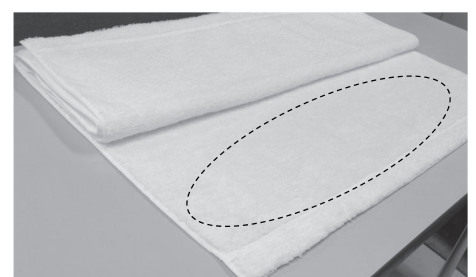

(b)
Fig.1 State of sample. 


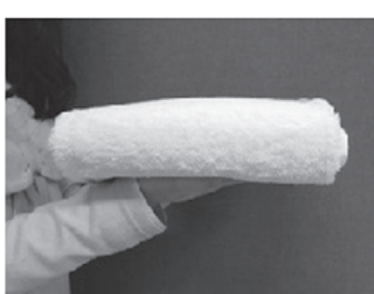

(a)

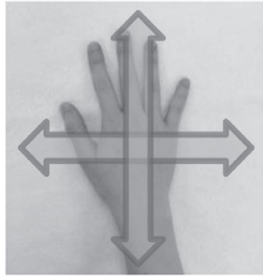

(c)

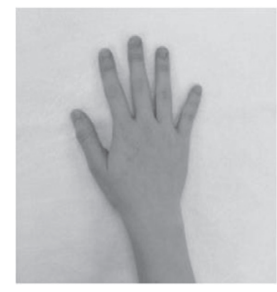

(b)

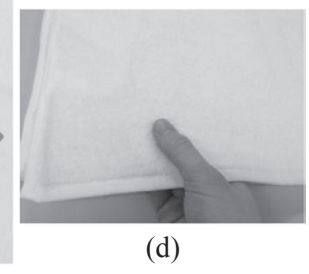

(d)

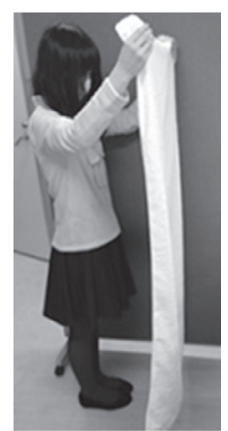

(e)
Fig.2 Movement for sensory evaluation.

なお，官能検査は消費者が店頭でバスタオルを購入するシー ンを想定したので，未洗濯の試料を用いた。

$\mathrm{SD}$ 法により, 被験者は各試料について, 19 種類の形容語 を 9 段階尺度（非常に, かなり, 少し, やや, どちらともい えない）で評価した。また，官能検査時に「評価しにくい形 容語」についても回答させた.

官能検査の再現性を良くするために, 各形容語について官 能評価する際の試技を以下のように設定した。これらの試技 はバスタオル購入時における消費者の動作 [2] を参考にした.

(1)「重い」は，Fig.2(a)に示すように12 枚折りの試料を両手 に乗せて評価.

(2)「あたたかい」は, Fig. 2(b) に示すように試料上に利き手 を置いて評価.

(3)「しっとりした」,「なめらかな」,「すべりやすい」,「パイ ルが長い」は, Fig.2(c)に示すように試料を利き手で上下 左右の 4 方向になでて評価.

(4)「しなやかな」,「厚い」，「ふんわりした」，「吸水性がよさ そう」,「がっしりした」，「高級感がある」，「肌になじむ」， 「乾きやすそう」，「がさがさした」は，Fig.2(d)に示すよう に試料を利き手の親指を上にしてはさみ, さらに指を動か して評価.このようなはさむ動作を行わせたのは，20〜 50 代の女性 44 名に対して予備実験を行った結果，バス夕 オル購入時における代表的な動作と判明したからである.

(5)「大きい」は, Fig.2(e)に示すように試料を両手で縦に広 げて評価.

(6)「肌触りがよい」，「好き」は，試技 (a)〜 (d) を用いて総 合評価.

なお，バスタオルの「触感」官能検査は実験環境 $\left(23^{\circ} \mathrm{C} \pm\right.$ $2^{\circ} \mathrm{C}$, 湿度 $45 \pm 5 \%$ R.H.) 下で 24 時間放置した試料を用いて, 環境 $\left(23^{\circ} \mathrm{C} \pm 2{ }^{\circ} \mathrm{C}\right.$, 湿度 $45 \pm 5 \%$ R.H. $)$ を調整した部屋で行っ た。

\section{3 バスタオルの物理特性の測定}

\section{（1）圧縮特性の測定}

本研究では, 先行研究 $[3,12]$ に基づいて引張圧縮試験機 (STA-1225,ORIENTEC 社製) を用いてバスタオルの圧縮特性 を測定した。官能検査で「ふんわりした」,「やわらかい」を 評価したときと同様にして，バスタオルは重ねずに 1 枚の状 態で圧縮特性を測定した。測定条件は，先行研究 [12]より 圧縮板の面積は $36.3 \mathrm{~cm}^{2}$, 圧縮速度は $1 \mathrm{~mm} / \mathrm{sec}$ とした。最大 圧力は, 夕オルのパイルが潰れる最小の圧力 $10 \mathrm{gf} / \mathrm{cm}^{2}$ [12] を用いた。

1 枚の試料上で異なる 5 箇所を測定したときを測定回数 1 回とし, 測定回数は 1 試料につき 5 回とした。実験環境は温 度 $23^{\circ} \mathrm{C} \pm 22^{\circ} \mathrm{C}$, 湿度 $50 \% \pm 4 \%$ R.H., 実験試料は実験環境下 で 24 時間放置した.

圧縮特性の測定項目は 8 種類（1)初期厚さ $\left(\mathrm{T}_{0}\right.$; 圧力 $0.5 \mathrm{gf} /$ $\mathrm{cm}^{2}$ 時における試料厚さ), (2)最大圧縮時の厚さ $\left(\mathrm{T}_{\mathrm{M}}\right.$; 最大 圧力 $10.0 \mathrm{gf} / \mathrm{cm}^{2}$ 時における試料厚さ), (3)試料の沈み込み量 $\left(\mathrm{T}_{0}\right.$ $\left.-\mathrm{T}_{\mathrm{M}}\right)$, (4)圧縮率 $\left(\mathrm{RA}=\left(\mathrm{T}_{0}-\mathrm{T}_{\mathrm{M}}\right) / \mathrm{T}_{0} \times 100\right)$, (5)圧縮仕 事量 (WC), (6)回復仕事量 (RWC), (7)圧縮回復性（RC = RWC / WC × 100)，8圧縮直線性（LC））である.

\section{（2）摩擦特性の測定}

表面摩擦測定試験機（NT - 01, カトーテック(株製）を用 いて, バスタオルの摩擦特性を測定した. 本実験では両面テー プを用いて試料をアクリル板に固定することで試料がずれる ことを防止した。

測定条件は先行研究 [12］に基づいて，摩擦子は人間の 指先を模擬した楕円形（長軸 $32 \mathrm{~mm} \times$ 短軸 $14 \mathrm{~mm}$ ) で荷重は $28 \mathrm{gf}$, 摩擦速度は $10 \mathrm{~mm} / \mathrm{sec}$, 測定距離は $110 \mathrm{~mm}$ である. 1 枚の試料上で異なる 5 箇所を測定したときを測定回数 1 回と し, 測定回数は 1 試料につき 5 回とした。実験環境は温度 $23^{\circ} \mathrm{C} \pm 2{ }^{\circ} \mathrm{C}$, 湿度 $50 \% \pm 4 \%$ R.H., 実験試料は実験環境下で 24 時間放置した。

摩擦特性測定項目は3 種類（1)平均摩擦係数 (MIU), (2) 摩擦係数の平均偏差 (MMD), (3) MIU/MMD (「乾湿感」を 表す物理量 [13]；すべりやすく，なめらかであるほど值が 大きくなる)）である.

\section{（3）温熱特性の測定}

接触移動熱量測定装置（NT - H1, カトーテック製）を用 いて，バスタオルの接触温冷感（q-max）を測定した。なお， $\mathrm{T}$ - box の大きさは $50 \times 50 \mathrm{~mm}$ である。測定回数は 5 回, 実験環境は温度 $23^{\circ} \mathrm{C} \pm 2^{\circ} \mathrm{C}$, 湿度 $50 \% \pm 4 \%$ R.H., 実験試料 は実験環境下で 24 時間放置した。 
Table 2 Average scores of hand.

\begin{tabular}{|c|c|c|c|c|c|c|c|c|c|c|c|c|c|}
\hline Polar word & \multirow{2}{*}{ (1) } & \multirow{2}{*}{ (2) } & \multirow{2}{*}{ (3) } & \multirow{2}{*}{ (4) } & \multirow{2}{*}{ (5) } & \multirow{2}{*}{ (6) } & \multirow{2}{*}{ (7) } & \multirow{2}{*}{ (8) } & \multirow{2}{*}{ (9) } & \multirow{2}{*}{ (10) } & \multirow{2}{*}{ (11) } & \multirow{2}{*}{ (12) } & \multirow{2}{*}{$\max -\min$} \\
\hline$(+)$ & & & & & & & & & & & & & \\
\hline warm - cold & -0.40 & 0.20 & 0.38 & -0.35 & 0.55 & 0.50 & 0.68 & 1.23 & 0.53 & 1.58 & 2.75 & 2.40 & 3.15 \\
\hline soft - hard & 1.18 & -1.25 & -1.18 & -0.35 & 0.18 & -0.95 & -0.03 & 1.45 & 1.33 & 2.65 & 2.73 & 3.33 & 4.58 \\
\hline flexible - stiff & 0.68 & -0.95 & -1.15 & -0.53 & 0.00 & -0.73 & -0.35 & 1.28 & 1.40 & 2.28 & 2.38 & 2.63 & 3.78 \\
\hline shittori - dry & -0.03 & -0.48 & -1.10 & -1.08 & -0.10 & -0.93 & -0.38 & 1.03 & 1.03 & 2.10 & 2.15 & 2.43 & 3.53 \\
\hline smooth - rough & 0.65 & -0.33 & -1.08 & -0.98 & -0.38 & -1.18 & -0.40 & 0.88 & 1.33 & 2.25 & 2.23 & 2.75 & 3.93 \\
\hline easy to slide - not slide & 0.93 & -0.15 & -0.20 & -0.28 & 0.03 & -0.68 & -0.18 & 1.03 & 1.28 & 2.15 & 2.10 & 2.13 & 2.83 \\
\hline heavy - light & -2.85 & 1.10 & 1.38 & -0.88 & 0.90 & 1.48 & 1.63 & 1.08 & -0.48 & -1.50 & -0.18 & -3.10 & 4.73 \\
\hline thick - thin & -2.85 & 0.90 & 0.23 & -1.00 & 0.30 & 0.88 & 0.93 & 0.75 & -0.63 & -0.65 & 1.78 & -0.88 & 4.63 \\
\hline large - small & -1.08 & 0.50 & 1.30 & -0.45 & 1.50 & 1.25 & 1.43 & 1.18 & 1.00 & 0.25 & 1.43 & 0.70 & 2.58 \\
\hline long pile - short pile & -0.75 & -0.90 & -1.05 & -1.35 & 0.15 & -0.55 & 0.45 & 1.03 & -0.58 & 0.98 & 0.90 & 0.93 & 2.38 \\
\hline full - poor & -1.55 & -0.65 & -1.00 & -0.93 & 0.20 & -0.25 & 0.18 & 1.35 & 0.80 & 1.88 & 2.85 & 2.95 & 4.50 \\
\hline $\begin{array}{l}\text { good water absorbent - } \\
\text { bad water absorbent }\end{array}$ & -0.30 & -0.18 & 0.18 & -0.40 & 0.48 & -0.08 & 0.63 & 1.43 & 0.98 & 1.25 & 1.63 & 0.75 & 2.03 \\
\hline sturdy - not & -2.90 & 1.85 & 0.85 & -0.78 & 0.65 & 1.55 & 0.88 & 0.35 & -0.90 & -1.93 & -0.08 & -2.40 & 4.75 \\
\hline high-class - not high class & -2.53 & -0.43 & -0.63 & -1.88 & -0.05 & 0.13 & 0.03 & 1.03 & 0.18 & 0.90 & 2.10 & 1.45 & 4.63 \\
\hline familiar with skin - not & 0.53 & -0.50 & -0.50 & -0.45 & 0.43 & -0.23 & 0.65 & 1.28 & 1.33 & 2.23 & 2.50 & 2.43 & 3.00 \\
\hline easy to dry - not dry & 2.13 & -0.80 & 0.40 & 0.70 & 0.13 & -0.83 & -0.45 & 0.13 & 1.13 & 1.25 & -0.20 & 1.00 & 2.96 \\
\hline feel rough - not rough & -0.95 & 0.05 & -0.20 & 0.15 & -0.50 & 0.00 & -0.25 & -1.33 & -1.33 & -2.55 & -2.95 & -3.10 & 3.25 \\
\hline good in touch - bad in touch & 0.00 & -0.55 & -0.90 & -0.78 & 0.20 & 0.03 & 0.30 & 1.23 & 1.53 & 2.45 & 2.75 & 3.13 & 4.03 \\
\hline like - dislike & -1.20 & -0.50 & -1.10 & -0.70 & -0.10 & -0.25 & 0.05 & 0.98 & 1.25 & 1.98 & 2.33 & 2.18 & 3.53 \\
\hline
\end{tabular}

\section{（4）吸水性の測定}

JIS L 1907 （繊維製品の吸水性試験方法）に準拠して，表 面吸水法により 3 種類の吸水性（最大吸水速度, 最大吸水速 度時点の吸水量, 飽和吸水量）を求めた。表面吸水法は布面 に垂直方向の吸水速度を測定する方法であり，ラローズ法と も呼ばれている. 測定回数は 5 回, 実験環境は温度 $23^{\circ} \mathrm{C} \pm 2{ }^{\circ} \mathrm{C}$, 湿度 $50 \% \pm 4 \%$ R.H., 実験試料は実験環境下で 24 時間放置 した。

なお，圧縮特性，摩擦特性，温熱特性，吸水性の測定には 官能検査試料と同様に未洗濯の試料を用いた。

\section{3. 実験結果及び考察}

\section{1 「触感」官能検査結果}

各形容語について求めた各試料の評定平均点, 評定平均点 の最大值と最小值との差 (Max - Min) を Table 2 に示す

Table 2 より, 試料(10は弱撚糸, 試料(11)と(12)は無撚糸をパイ ル糸に用いているので, これら 3 試料は「肌触りがよい」,「好 き」の評価が高い. よって，パイル糸の撚り数が少ないほど 「肌触りがよい」と評価される傾向がみられた。

試料(4)の触感が悪いのは，先晒しタオルであるからと考え られる。試料(2)と(6)は，ともに目付が $500 \mathrm{~g} / \mathrm{m}^{2}$ 以上で重く, 太番手で, 糸密度がやや高い。 そのため, これら 2 試料は「や わらかい」「「しなやかな」ではなく，「がっしりした」と評 価されたと考えられる.
また, Table 2 より「やわらかい」,「重い」,「厚い」,「ふん わりした」,「がっしりした」「高級感がある」,「肌触りがよい」 は試料間の評定平均点差 $(\mathrm{Max}-\mathrm{Min})$ が大きいので，評価 しやすい形容語であることがわかった。一方で，「パイルが 長い」,「吸水性がよさそう」は試料間の評定平均点差が小さ く，評価しにくい形容語であることがわかった。

これは，官能検査と同時に「評価しにくい形容語は？」と いうアンケート調査結果より, 評価しにくい形容語は「パイ

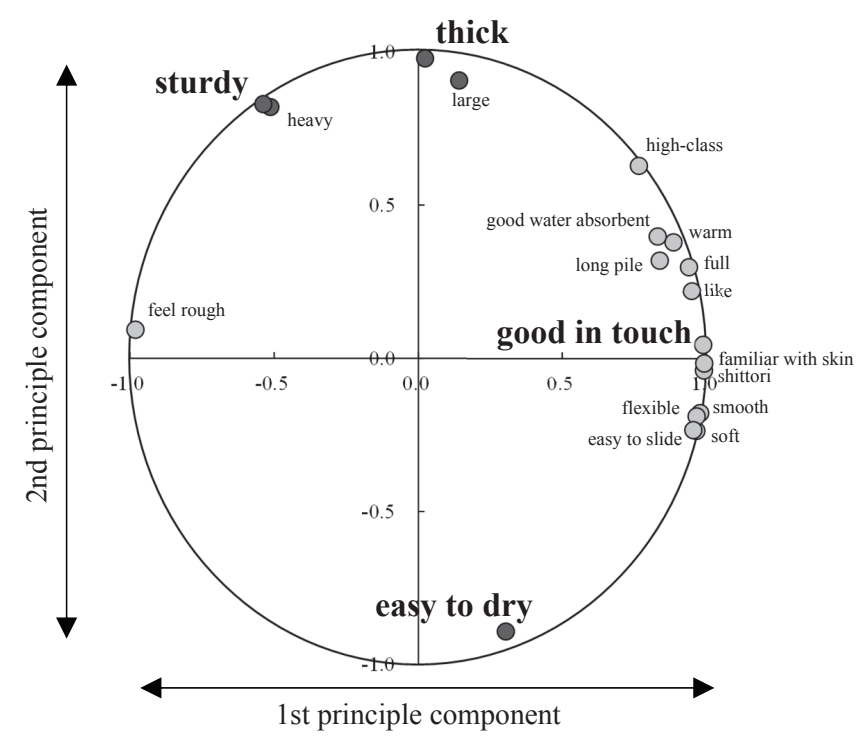

Fig.3 Principal component loadings. 
Table 3 Correlation coefficient among each adjective.

\begin{tabular}{c|c|c|c|c|c|c|c|c|c|c}
\hline & warm & soft & flexible & shittori & smooth & easy to slide & heavy & thick & large & long pile \\
\hline \hline warm & - & 0.759 & 0.778 & 0.851 & 0.775 & 0.750 & -0.193 & 0.411 & 0.456 & 0.839 \\
\hline soft & 0.759 & - & 0.991 & 0.957 & 0.964 & 0.964 & -0.686 & -0.210 & -0.078 & 0.760 \\
\hline flexible & 0.778 & 0.991 & - & 0.977 & 0.976 & 0.974 & -0.638 & -0.150 & -0.029 & 0.755 \\
\hline shittori & 0.851 & 0.957 & 0.977 & - & 0.983 & 0.967 & -0.539 & -0.010 & 0.089 & 0.806 \\
\hline smooth & 0.775 & 0.964 & 0.976 & 0.983 & - & 0.987 & -0.653 & -0.152 & -0.056 & 0.718 \\
\hline easy to slide & 0.750 & 0.964 & 0.974 & 0.967 & 0.987 & - & -0.663 & -0.188 & -0.092 & 0.686 \\
\hline heavy & -0.193 & -0.686 & -0.638 & -0.539 & -0.653 & -0.663 & - & 0.780 & 0.690 & -0.138 \\
\hline thick & 0.411 & -0.210 & -0.150 & -0.010 & -0.152 & -0.188 & 0.780 & - & 0.834 & 0.301 \\
\hline large & 0.456 & -0.078 & -0.029 & 0.089 & -0.056 & -0.092 & 0.690 & 0.834 & - & 0.391 \\
\hline long pile & 0.839 & 0.760 & 0.755 & 0.806 & 0.718 & 0.686 & -0.138 & 0.301 & 0.391 & - \\
\hline full & 0.960 & 0.833 & 0.860 & 0.915 & 0.840 & 0.805 & -0.270 & 0.312 & 0.394 & 0.861 \\
\hline good water absorbent & 0.813 & 0.715 & 0.758 & 0.804 & 0.718 & 0.727 & -0.005 & 0.398 & 0.512 & 0.848 \\
\hline sturdy & -0.168 & -0.724 & -0.670 & -0.548 & -0.655 & -0.689 & 0.955 & 0.813 & 0.648 & -0.208 \\
\hline hight-class & 0.927 & 0.577 & 0.630 & 0.737 & 0.619 & 0.578 & 0.106 & 0.625 & 0.683 & 0.814 \\
\hline familiar with skin & 0.857 & 0.968 & 0.975 & 0.977 & 0.955 & 0.944 & -0.509 & 0.005 & 0.137 & 0.846 \\
\hline easy to dry & -0.104 & 0.504 & 0.457 & 0.324 & 0.445 & 0.512 & -0.826 & -0.901 & -0.669 & -0.026 \\
\hline feel rough & -0.871 & -0.961 & -0.967 & -0.975 & -0.968 & -0.970 & 0.598 & 0.055 & -0.054 & -0.762 \\
\hline good in touch & 0.890 & 0.939 & 0.960 & 0.978 & 0.946 & 0.918 & -0.488 & 0.059 & 0.185 & 0.823 \\
\hline like & 0.905 & 0.854 & 0.894 & 0.938 & 0.877 & 0.847 & -0.319 & 0.239 & 0.312 & 0.812 \\
\hline
\end{tabular}

\begin{tabular}{c|c|c|c|c|c|c|c|c|c}
\hline & full & $\begin{array}{c}\text { good water } \\
\text { absorbent }\end{array}$ & sturdy & hight-class & $\begin{array}{c}\text { familiar with } \\
\text { skin }\end{array}$ & easy to dry & feel rough & $\begin{array}{c}\text { good in } \\
\text { touch }\end{array}$ & like \\
\hline \hline warm & 0.960 & 0.813 & -0.168 & 0.927 & 0.857 & -0.104 & -0.871 & 0.890 & 0.905 \\
\hline soft & 0.833 & 0.715 & -0.724 & 0.577 & 0.968 & 0.504 & -0.961 & 0.939 & 0.854 \\
\hline flexible & 0.860 & 0.758 & -0.670 & 0.630 & 0.975 & 0.457 & -0.967 & 0.960 & 0.894 \\
\hline shittori & 0.915 & 0.804 & -0.548 & 0.737 & 0.977 & 0.324 & -0.975 & 0.978 & 0.938 \\
\hline smooth & 0.840 & 0.718 & -0.655 & 0.619 & 0.955 & 0.445 & -0.968 & 0.946 & 0.877 \\
\hline easy to slide & 0.805 & 0.727 & -0.689 & 0.578 & 0.944 & 0.512 & -0.970 & 0.918 & 0.847 \\
\hline heavy & -0.270 & -0.005 & 0.955 & 0.106 & -0.509 & -0.826 & 0.598 & -0.488 & -0.319 \\
\hline thick & 0.312 & 0.398 & 0.813 & 0.625 & 0.005 & -0.901 & 0.055 & 0.059 & 0.239 \\
\hline large & 0.394 & 0.512 & 0.648 & 0.683 & 0.137 & -0.669 & -0.054 & 0.185 & 0.312 \\
\hline long pile & 0.861 & 0.848 & -0.208 & 0.814 & 0.846 & -0.026 & -0.762 & 0.823 & 0.812 \\
\hline full & - & 0.853 & -0.262 & 0.917 & 0.914 & -0.007 & -0.891 & 0.951 & 0.978 \\
\hline good water absorbent & 0.853 & - & -0.123 & 0.852 & 0.836 & -0.002 & -0.750 & 0.807 & 0.860 \\
\hline sturdy & -0.262 & -0.123 & - & 0.114 & -0.555 & -0.922 & 0.602 & -0.496 & -0.324 \\
\hline hight-class & 0.917 & 0.852 & 0.114 & - & 0.734 & -0.336 & -0.699 & 0.794 & 0.874 \\
\hline familiar with skin & 0.914 & 0.836 & -0.555 & 0.734 & - & 0.323 & -0.966 & 0.981 & 0.932 \\
\hline easy to dry & -0.007 & -0.002 & -0.922 & -0.336 & 0.323 & - & -0.374 & 0.241 & 0.074 \\
\hline feel rough & -0.891 & -0.750 & 0.602 & -0.699 & -0.966 & -0.374 & - & -0.962 & -0.896 \\
\hline good in touch & 0.951 & 0.807 & -0.496 & 0.794 & 0.981 & 0.241 & -0.962 & - & 0.966 \\
\hline like & 0.978 & 0.860 & -0.324 & 0.874 & 0.932 & 0.074 & -0.896 & 0.966 & - \\
\hline
\end{tabular}

ルが長い」,「吸水性がよさそう」，「あたたたかい」であった ことと一致している

各被験者が各形容語について評価した各試料の評定平均 点について分散分析を行った結果, 全ての形容語において 試料間に $1 \%$ で有意差がみられた。各形容語間の相関係数を Table 3 に示す.

Table 3 より，「肌触りがよい」は，「しっとりした，なめら かな, すべりやすい, やわらかい, ふんわりした，あたたかい， パイルが長い，吸水性がよさそう」と正の相関，「がさがさ した」と負の相関がみられた。また、「乾きやすそう」は「がっ しりした, 重い, 厚い, 大きい」と負の相関がみられた。「がっ
しりした」は,「重い, 厚い, 大きい」と正の相関がみられた。 次に, バスタオルの「触感」評価要因を検討するために, Table 2 に示す各形容語の評定平均点について主成分分析を 行った結果を Fig. 3 に示す。 なお, 主成分の選定条件は, 固 有值が 1.0 以上，累積寄与率 $80 \%$ 以上とした。本研究では， 試料について測定した多数の評価形容語より少数の主成分を 合成する主成分分析を用いた。

Fig. 3 より，バスタオルの「触感」を評価する主成分は 2 種類抽出された。第 1 主成分は,「肌触りがよい, 肌になじむ, しっとりした, ふんわりした, やわらかい」がみられ,「肌 触りがよい」に関連する主成分と考えられる。第 2 主成分は， 


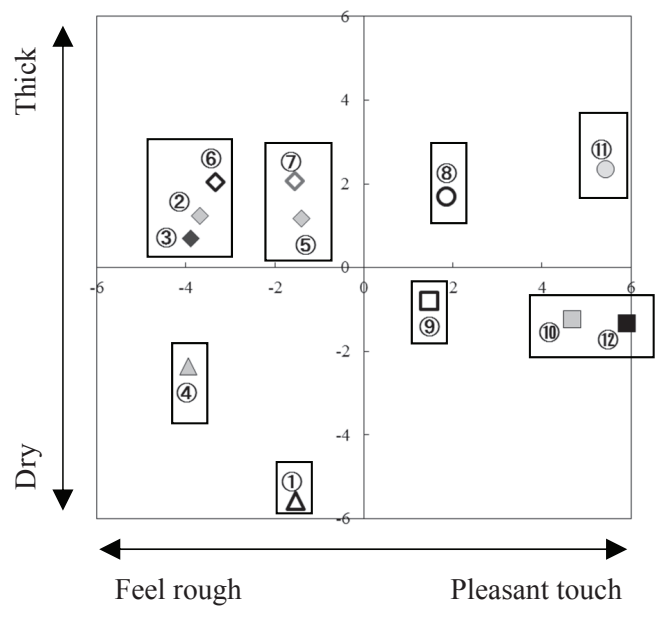

Fig.4 Principal component scores.

「がっしりした，乾きやすそう」がみられ，「がっしり感と乾 燥性」に関連する主成分と考えられる。この結果は, Singh らが提案したタオルの風合い形容語「ふくらみ, ソフトさ」 と一致している。しかし, 本研究では試料をバスタオルに限 定したこと, 被験者が専門家ではなく消費者であったので, バスタオルを特徴づける形容語「肌になじむ，しっとりした， がっしりした，乾きやすそう」も抽出されたと考えられる．

次に, 各試料の「触感」について, その特徵を明確化する ために主成分得点を算出した。算出した主成分得点より評価 が類似した試料をまとめ，12 試料をいくつかのグループに 分類するために，各試料の第 1 主成分得点と第 2 主成分得点 を用いてクラスター分析を行った。ここで，クラスター分析 とは得られたサンプルの全ての組み合わせについて距離を算 出し，その距離の近いサンプル同士を群（クラスター）とし てまとめ，いくつかの集団に分類する手法である.

12 試料における主成分得点に基づいてクラスター分析を 行い, グループ分けした結果を Fig. 4 に示す. 実線の枠で示 した群がクラスターである

Fig. 4 において，第 1 象限より，試料111「非常に肌触り がよく, 厚くてがっしりした」イメージ, 試料(8は「やや肌
触りがよく, 厚くてがっしりした」イメージ, 試料(5)と(7)は「や や，がっしりした」イメージ，試料(2)，(3)，(6) は非常にが さがさした」イメージ，試料(4)は「非常にがさがさして，乾 きやすそうな」イメージ，試料(1)は「非常に薄くて，乾きや すそうな」イメージ，試料(9)は「や肌触りがよい」イメー ジ, 試料(10), (12)は「非常に肌触りがよい」イメージであるこ とがわかる。

\section{$3.2\lceil$ 触感」と物理特性との相関}

各試料について圧縮特性を測定した結果を Table 4 に示す、 Table 4 より, 試料(6), (7), 8), (11), 12)は厚いバスタオルである. 圧縮率（RA）より，試料(1)，(7)，(10)，(12)は沈み込みやすい, 圧縮仕事量（WC）より，試料(8), (11), (12)は圧縮されやすい, 圧縮回復性（RC）より，試料(1), (3), (11)は圧縮後の回復性 が良いことがわかる。

測定した圧縮特性と「触感」評価形容語間の相関係数を Table 5 に示す.

Table 5 より, 初期厚さ $\left(\mathrm{T}_{0}\right)$ は「あたたかい, 厚い, パイ ルが長い，ふんわりした，吸水性がよさそう，高級感がある」 と正の相関がみられた。また，試料の厚さ $\left(\mathrm{T}_{0}\right)$ が薄いほど, 「乾きやすそう」と評価する傾向がみられた。

沈み込み量 $\left(\mathrm{T}_{0}-\mathrm{T}_{\mathrm{M}}\right)$ は, 「あたたかい, やわらかい, し なやかな, しっとりした, パイルが長い, ふんわりした，吸 水性がよさそう, 高級感がある, 肌になじむ, 肌触りがよい」 と正の相関がみられた。圧縮仕事量 (WC) 及び回復仕事量 (RWC) は,「やわらかい, しなやかな, しっとりした, パイ ルが長い, ふんわりした, 高級感がある, 肌になじむ, 肌触 りがよい」と正の相関がみられた。

特に，「やわらかい，しなやかな，しっとりした，パイル が長い, 肌になじむ, 肌触りがよい」は, 沈み込み量 $\left(\mathrm{T}_{0}-\right.$ $\mathrm{TM})$, 圧縮率 (RA), 圧縮仕事量 (WC), 回復仕事量 (RWC) と有意な正の相関がみられた。

このように, 被験者は試料の初期厚さ, 沈み込み量, 圧縮 しやすさ，回復しやすさなどをもとに，バスタオルの「触感」 を評価していることがわかった。

被験者が「しっとりした，なめらかな，すべりやすい，パ

Table 4 Result of Compression properties.

\begin{tabular}{|c|c|c|c|c|c|c|c|c|}
\hline Sample & $\mathrm{To}(\mathrm{mm})$ & $\mathrm{T}(\mathrm{mm})$ & $\mathrm{T}_{0}-\mathrm{T}_{\mathrm{M}}(\mathrm{mm})$ & $\mathrm{RA}(\%)$ & $\mathrm{WC}\left(\mathrm{gf} \cdot \mathrm{cm}^{2}\right)$ & $\mathrm{RWC}\left(\mathrm{gf} \cdot \mathrm{cm}^{2}\right)$ & $\mathrm{RC}(\%)$ & $\mathrm{LC}(-)$ \\
\hline (1) & 4.50 & 2.24 & 2.26 & 50.25 & 16.09 & 6.69 & 41.55 & 0.04 \\
\hline (2) & 6.80 & 4.54 & 2.26 & 33.09 & 18.81 & 7.27 & 38.58 & 0.05 \\
\hline (3) & 6.19 & 4.05 & 2.14 & 34.51 & 18.01 & 7.69 & 42.67 & 0.05 \\
\hline (4) & 4.92 & 3.01 & 1.91 & 38.78 & 15.85 & 6.23 & 39.31 & 0.05 \\
\hline (5) & 7.09 & 3.89 & 3.20 & 45.19 & 23.06 & 8.91 & 38.65 & 0.04 \\
\hline (6) & 8.42 & 5.47 & 2.95 & 35.02 & 29.05 & 10.71 & 36.88 & 0.05 \\
\hline (7) & 8.50 & 3.96 & 4.53 & 53.35 & 29.72 & 9.75 & 32.86 & 0.04 \\
\hline (8) & 8.29 & 4.34 & 3.94 & 47.58 & 35.29 & 11.26 & 31.92 & 0.05 \\
\hline (9) & 6.31 & 3.43 & 2.88 & 45.61 & 26.29 & 9.30 & 35.39 & 0.05 \\
\hline (10) & 6.08 & 3.02 & 3.06 & 50.26 & 26.81 & 9.34 & 34.85 & 0.05 \\
\hline (11) & 9.47 & 5.55 & 3.92 & 41.35 & 36.42 & 14.69 & 40.34 & 0.05 \\
\hline (12) & 8.17 & 3.11 & 5.05 & 61.90 & 39.30 & 15.36 & 39.11 & 0.04 \\
\hline
\end{tabular}


Table 5 Correlation coefficient between sensory values and compression properties.

\begin{tabular}{|c|c|c|c|c|c|c|c|c|}
\hline & $\mathrm{T}_{0}$ & Тм & То-Тм & RA & WC & RWC & $\mathrm{RC}$ & LC \\
\hline warm & 0.715 & 0.340 & 0.758 & 0.421 & 0.874 & 0.925 & -0.142 & 0.022 \\
\hline soft & 0.230 & -0.252 & 0.605 & 0.740 & 0.658 & 0.681 & -0.149 & -0.189 \\
\hline flexible & 0.260 & -0.181 & 0.580 & 0.673 & 0.679 & 0.695 & -0.186 & -0.086 \\
\hline shittori & 0.360 & -0.078 & 0.629 & 0.632 & 0.727 & 0.741 & -0.214 & -0.053 \\
\hline smooth & 0.234 & -0.199 & 0.557 & 0.658 & 0.635 & 0.666 & -0.132 & -0.093 \\
\hline easy to slide & 0.161 & -0.227 & 0.473 & 0.609 & 0.570 & 0.611 & -0.073 & -0.033 \\
\hline heavy & 0.402 & 0.706 & -0.088 & -0.601 & -0.053 & -0.167 & -0.301 & 0.325 \\
\hline thick & 0.803 & 0.913 & 0.321 & -0.390 & 0.438 & 0.395 & -0.287 & 0.359 \\
\hline large & 0.790 & 0.724 & 0.489 & -0.113 & 0.543 & 0.497 & -0.310 & 0.102 \\
\hline long pile & 0.648 & 0.150 & 0.844 & 0.649 & 0.849 & 0.767 & -0.497 & -0.212 \\
\hline full & 0.641 & 0.211 & 0.773 & 0.524 & 0.888 & 0.893 & -0.301 & 0.020 \\
\hline good water absorbent & 0.583 & 0.253 & 0.642 & 0.401 & 0.768 & 0.687 & -0.473 & 0.149 \\
\hline sturdy & 0.435 & 0.779 & -0.110 & -0.679 & -0.058 & -0.119 & -0.167 & 0.335 \\
\hline hight-class & 0.825 & 0.528 & 0.739 & 0.269 & 0.893 & 0.873 & -0.370 & 0.169 \\
\hline familiar with skin & 0.410 & -0.069 & 0.697 & 0.690 & 0.764 & 0.767 & -0.255 & -0.130 \\
\hline easy to dry & -0.669 & -0.867 & -0.161 & 0.505 & -0.219 & -0.175 & 0.231 & -0.263 \\
\hline feel rough & -0.336 & 0.084 & -0.599 & -0.611 & -0.699 & -0.764 & 0.044 & 0.074 \\
\hline good in touch & 0.469 & 0.010 & 0.709 & 0.640 & 0.813 & 0.826 & -0.255 & -0.066 \\
\hline like & 0.542 & 0.145 & 0.687 & 0.507 & 0.827 & 0.814 & -0.352 & 0.102 \\
\hline
\end{tabular}

イルが長い」を評価するときに試料を 1 方向ではなく上下左 右 4 方向に触れていたので, パイル糸に対して順目方向（パ イルの根元からパイル先端へ摩擦する方向), 逆目方向それ ぞれに試料のたて糸方向とよこ糸方向について摩擦特性を測 定した，そして，「順目方向（たて方向，よこ方向）」と「逆 目方向（たて方向，よこ方向）」の 4 方向の摩擦特性の平均 值を求めた。算出した結果を Table 6 に示す。また, 各試料 について測定した q-max の結果, 表面吸水法により測定した 吸水性の結果も Table 6 に示す。

測定した摩擦特性, 温熱特性及び吸水性と「触感」評価形 容語間の相関係数を Table 7 に示す.

Table 7 より, 摩擦係数の平均偏差 (MMD) と「なめらかな」, 「すべりやすい」と負の相関がみられた。また, Table 7 にお
いて，「乾湿感」を表す MID/MMDは「乾きやすそう」と相 関がみられなかった

Table 6 より, 薄い試料である(1), (4), (10)の q-max は大きく, 無撚糸タオル(11), (12)の q-max は小さい. これは, パイル糸に 撚りがないのでパイル層内の含気率が高くなって熱を逃がし にくくなり，無撚糸タオル111, (12) q-max が小さくなったと 考えられる. Table 7 よ，「あたたかい」と q-max 間に5\% 有意の負の相関がみられた

Table 6 上り, 試料(2), (3), (6)の最大吸水速度, 最大吸水速 度時点の吸水量及び飽和吸水量は大きい.

測定した吸水性と「触感」との相関関係を Table 7 に示す. Table 7 より,「吸水性がよさそう」と「吸水性」測定值とは 相関がみられなかった。これは, Table 3 より「吸水性がよさ

Table 6 Result of friction and thermal properties, and water absorbency.

\begin{tabular}{c|c|c|c|c|c|c|c}
\hline & MIU(-) & MMD(-) & $\begin{array}{c}\text { MIU/MMD } \\
(-)\end{array}$ & $\begin{array}{c}\text { q-max } \\
{\left[\mathrm{w} \cdot 10^{-2} / \mathrm{cm}^{2}\right]}\end{array}$ & $\begin{array}{c}\text { Maximum water } \\
\text { absorption speed } \\
(\mathrm{m} / \mathrm{s})\end{array}$ & $\begin{array}{c}\text { Amount of water } \\
\text { absorption } \\
(\mathrm{ml})\end{array}$ & $\begin{array}{c}\text { Amount of saturation } \\
\text { water absorption } \\
\left(\mathrm{m} / \mathrm{m}^{2}\right)\end{array}$ \\
\hline \hline (1) & 0.247 & 0.035 & 7.294 & 3.36 & 0.07 & 0.07 & 500 \\
\hline$(2)$ & 0.292 & 0.053 & 5.869 & 3.18 & 0.17 & 0.32 & 1750 \\
\hline$(3)$ & 0.270 & 0.045 & 6.446 & 2.94 & 0.18 & 0.33 & 1650 \\
\hline$(4)$ & 0.276 & 0.038 & 7.900 & 3.36 & 0.13 & 0.15 & 1310 \\
\hline$(5)$ & 0.318 & 0.066 & 5.405 & 3.14 & 0.10 & 0.18 & 1390 \\
\hline$(6)$ & 0.336 & 0.046 & 8.387 & 3.16 & 0.15 & 0.25 & 2220 \\
\hline$(7)$ & 0.237 & 0.040 & 6.448 & 3.18 & 0.12 & 0.18 & 1560 \\
\hline$(8)$ & 0.278 & 0.036 & 8.113 & 3.28 & 0.09 & 0.15 & 1070 \\
\hline$(9)$ & 0.310 & 0.041 & 7.724 & 3.32 & 0.16 & 0.27 & 1570 \\
\hline (10 & 0.290 & 0.034 & 9.229 & 3.40 & 0.02 & 0.02 & 120 \\
\hline (11) & 0.302 & 0.052 & 6.872 & 2.86 & 0.12 & 0.23 & 1840 \\
\hline (12) & 0.342 & 0.067 & 5.231 & 2.66 & 0.04 & 0.05 & 830 \\
\hline
\end{tabular}


Table 7 Correlation coefficient between sensory values and three properties.

\begin{tabular}{|c|c|c|c|c|c|c|c|}
\hline & MIU & $\mathrm{MMD}$ & $\mathrm{MIU} / \mathrm{MMD}$ & $\mathrm{q}-\max$ & $\begin{array}{l}\text { Maximum water } \\
\text { absorption speed }\end{array}$ & $\begin{array}{c}\text { Amount of water } \\
\text { absorption }\end{array}$ & $\begin{array}{c}\text { Amount of saturation } \\
\text { water absorption }\end{array}$ \\
\hline warm & 0.106 & -0.182 & 0.247 & -0.640 & -0.406 & -0.234 & -0.073 \\
\hline soft & -0.217 & -0.557 & 0.539 & -0.252 & -0.805 & -0.738 & -0.594 \\
\hline flexible & -0.186 & -0.546 & 0.551 & -0.232 & -0.749 & -0.674 & -0.543 \\
\hline smooth & -0.258 & -0.577 & 0.519 & -0.280 & -0.731 & -0.634 & -0.546 \\
\hline easy to slide & -0.348 & -0.640 & 0.542 & -0.239 & -0.725 & -0.636 & -0.578 \\
\hline heavy & 0.508 & 0.650 & -0.392 & 0.066 & 0.675 & 0.755 & 0.716 \\
\hline thick & 0.518 & 0.474 & -0.216 & -0.339 & 0.453 & 0.615 & 0.709 \\
\hline hrge & 0.604 & 0.493 & -0.148 & -0.460 & 0.294 & 0.466 & 0.576 \\
\hline long pile & 0.175 & -0.041 & 0.177 & -0.302 & -0.669 & -0.498 & -0.347 \\
\hline full & 0.134 & -0.234 & 0.368 & -0.491 & -0.522 & -0.380 & -0.188 \\
\hline good water absorbent & 0.068 & -0.265 & 0.450 & -0.214 & -0.455 & -0.294 & -0.185 \\
\hline sturdy & 0.556 & 0.704 & -0.474 & -0.062 & 0.768 & 0.849 & 0.823 \\
\hline hight-class & 0.333 & 0.040 & 0.164 & -0.530 & -0.230 & -0.040 & 0.105 \\
\hline familiar with skin & -0.135 & -0.455 & 0.482 & -0.308 & -0.734 & -0.621 & -0.465 \\
\hline easy to dry & -0.628 & -0.687 & 0.440 & 0.240 & -0.621 & -0.722 & -0.806 \\
\hline feel rough & 0.218 & 0.508 & -0.441 & 0.421 & 0.676 & 0.564 & 0.460 \\
\hline good in touch & -0.038 & -0.384 & 0.435 & -0.375 & -0.656 & -0.544 & -0.383 \\
\hline like & 0.034 & -0.325 & 0.435 & -0.346 & -0.545 & -0.424 & -0.251 \\
\hline
\end{tabular}

そう」と「あたたかい, パイルが長い, ふんわりした」とは 正の相関がみられ，被験者は「あたたかい，パイルが長い， ふんわりした」と感じると「吸水性がよさそう」と評価した からと考えられる。一方, 最大吸水速度, 最大吸水速度時点 の吸水量及び飽和吸水量は「乾きやすそう」と負の相関がみ られた。

したがって，被験者の「吸水性がよさそう」のイメージと 実際の吸水性は一致しないことがわかった。

\section{4. 結 言}

12 種類の市販バスタオルについて 20 ～ 50 代女性が SD 法 による「触感」官能検査を行った。 さらに, バスタオルの物 理特性を測定して, 種々の物理特性と「触感」との相関関係 を検討した。その結果，得られた知見を以下に示す。

（1）主成分分析を行った結果，バスタオルの「触感」は「肌 触りのよさ」,「がっしり感と乾燥性」により評価される ことがわかった

（2）圧縮特性と「触感」との相関関係より，沈み込み量 $\left(\mathrm{T}_{0}\right.$ - $\mathrm{T}_{\mathrm{M}}$ ), 圧縮率 (RA), 圧縮仕事量 (WC) 及び回復仕 事量 (RWC) は「やわらかい,しなやかな,しっとりした, ふんわりした，高級感がある，肌になじむ，肌触りがよ い」と正の相関がみられた。

(3) 摩擦特性と「触感」との相関関係より, 摩擦係数の平均 偏差（MMD）は「なめらかな, すべりやすい」と負の 相関がみられた。

（4）温熱特性と「触感」との相関関係より，「あたたかい」 は接触温冷感（q-max）と負の相関がみられた。

（5）吸水性とイメージ形容語「吸水性がよさそう」との間に は，有意な相関はみられなかった。しかし，「乾きやす そう」は最大吸水速度, 最大吸水速度時点の吸水量, 飽 和吸水量と負の相関がみられた。

\section{謝 辞}

本研究の一部は, 科研費 (基盤研究 (S)No.24220012) の助 成を受けて行ったものである。

\section{References}

[1] JIS L 0212-3 (1999) Glossary of textile terms Part3:bedding, others

[2] Questionaire about Bath Towel (August, 2012) Ryohin Keikaku

[3] Nishimatsu T, Sawaki T (1982) J Text Mach Soc Japan (predecessor journal of J Text Eng), 35, T146-T152

[4] Nishimatsu T, Sawaki T (1984) Text Res J, 54, 699-705

[5] Nishimatsu T, Sakai T (1985) Sen'i Gakkaishi, 41, T396T402

[6] Nishimatsu T, Sakai T (1985) Sen'i Gakkaishi, 41, T438T447

[7] Nishimatsu T, Sakai T (1987) Sen'i Gakkaishi, 43, 553-557

[8] Nishimatsu T, Sakai T (1988) Sen'i Gakkaishi, 44, 88-95

[9] Takatera M, Kunihiro S, Yazaki Y, Otake A, Shimizu Y (2005) J Kansei Eng Japan, 5, 103-110

[10] Singh J.P., Behere B.K., Matsudaira M (2014) J Text Inst, 105, 467-476

[11] Kats D (2003) "Shokkaku no Sekai", 55-134, Shinyousha

[12] KamuraW, Hyodo H, Kanai H, Nishimatsu T, Ogura E (2012) Japanese J Ergonomics 2012 Meeting Proceedings, 52-53

[13] Kawazu K, KoikeK, Imada M, Yasuda K (1999) Automotive Eng Japan, 1999 Proceedings (No.87-99), 19-22 